A N N A L E S

UNIVERSITATIS MARIAE CURIE-SKŁODOWSKA LUBLIN - POLONIA

VOL. LXX, z. 1

SECTIO B

2015

Zakład Meteorologii i Klimatologii, Wydział Nauk o Ziemi i Gospodarki Przestrzennej

Uniwersytet Marii Curie-Skłodowskiej, al. Kraśnicka 2cd, 20-718 Lublin

e-mail: boguslaw.kaszewski@umcs.lublin.pl; anna.bilik@poczta.umcs.lublin.pl

BOGUSŁAW MICHAŁ KASZEWSKI, ANNA BILIK

\title{
Zmiany średniej dobowej temperatury powietrza w Lublinie w latach 1951-2010
}

The changes of mean daily air temperature in Lublin in the years 1951-2010

\begin{abstract}
Słowa kluczowe: średnia dobowa temperatura powietrza, przedziały temperatury, Lublin, meteorologia, klimatologia tology

Key words: mean daily air temperature, temperature intervals, Lublin, meteorology, clima-
\end{abstract}

\section{WSTĘP}

Do charakterystyki stosunków termicznych, najczęściej wykorzystywane są wartości średnie miesięczne, sezonowe i roczne (na podstawie średnich dobowych, maksymalnych i minimalnych temperatur powietrza). Wskaźniki te pozwalają na uzyskanie ogólnego obrazu warunków termicznych i ich zmian na danym obszarze czy w danym punkcie. Rzadziej wykorzystywane są do analizy wartości dobowe temperatury: średnia, maksymalna i minimalna. Najpełniej charakteryzująca dobę pod względem termicznym wartość średnia stosowana jest do wyznaczania m.in.: początku i końca pór roku (Czernecki, Miętus 2010) i okresu wegetacyjnego (np. Mager, Kopeć 2010), zmienności temperatury z dnia na dzień (Fortuniak i in. 2004), dobowych typów pogody (Fiedorow 1925, Piotrowicz 2010), stopniodni chłodu i ciepła (Wibig 2004), określania częstości występowania dni charakterystycznych (np. Kossowska-Cezak 2005), anomalii chłodu i ciepła (Krępa, Ciaranek 2014, Řezníčková 2007). Jak wykazały badania (Kożuchowski 2004; Kossowska-Cezak, Wawer 2014), zmiany rozkładu częstości średnich dobowych wartości temperatury powietrza mogą być dobrym wskaźnikiem zmian klimatu danego obszaru. 
Celem pracy jest porównanie warunków termicznych w Lublinie w dwóch okresach: 1951-1980 i 1981-2010 przy wykorzystaniu wartości średnich dobowych temperatury. Przeanalizowano zakres zmienności temperatury powietrza i częstość wartości dobowych w przedziałach 2-stopniowych i 5-stopniowych stosowane w pracy (Kossowska-Cezak, Wawer 2014).

Materiałem wyjściowym były średnie dobowe wartości temperatury powietrza ze Stacji Meteorologicznej UMCS z lat 1952-2010. Ponieważ seria systematycznych spostrzeżeń w Stacji UMCS rozpoczęła się dopiero 1.X.1951 r., dane z tego roku pochodzą z nieistniejącej już Stacji Synoptycznej PIHM (obecnie IMGW) znajdującej się przy placu Bychawskim w Lublinie (Zinkiewicz, Warakomski 1959). Stacja PIHM była położona w odległości ok. 2 km od Stacji UMCS i jak wykazały badania nie było istotnych różnic w wartościach temperatury powietrza między tymi stacjami (Badach i in. 1985). Dlatego też przyjęto jednorodność całej serii pomiarowej za lata 1951-2010.

\section{OGÓLNA CHARAKTERYSTYKA TERMICZNA OKRESÓW 1951-1980 I 1981-2010 W LUBLINIE}

Średnia temperatura powietrza w Lublinie w okresie 1981-2010 wyniosła $8,7^{\circ} \mathrm{C}$ i była wyższa o $0,8^{\circ} \mathrm{C}$ od średniej z lat $1951-1980$ (Tab. 1). W przebiegu rocznym w 10 miesiącach średnia temperatura w okresie późniejszym (19812010) była wyższa niż w okresie wcześniejszym (1951-1980). Największe różnice dotyczyły miesięcy od stycznia do marca (odpowiednio: $1,6^{\circ} \mathrm{C}, 1,5^{\circ} \mathrm{C}$ i $1,5^{\circ} \mathrm{C}$ ). W czerwcu i listopadzie w obu okresach temperatury były takie same. W tych miesiącach w okresie 1951-2005 w wielu stacjach w Polsce stwierdzono nawet lekki spadek temperatury powietrza (Michalska 2011).

W przypadku najwyższych miesięcznych i rocznych temperatur powietrza wyższe wartości w latach 1981-2010 wystąpiły w 9 miesiącach i w roku (Tab. 2). Niższe wartości maksymalne notowano w czerwcu, wrześniu i październiku. Najniższe temperatury średnie były wyższe w latach 1981-2010 w 8 miesiącach (Tab. 3). Warto zwrócić uwagę na sierpień, w którym w drugim analizowanym okresie wystąpiła zarówno wartość najwyższa średnia miesięczna $22,3^{\circ} \mathrm{C}$, jak

Tabela 1. Wartości średnie miesięczne i roczne temperatury powietrza w Lublinie w latach 1981-2010 i w latach $1951-1980\left(\mathrm{w}^{\circ} \mathrm{C}\right)$

Table 1 . The mean monthly values and mean annual values of air temperature in Lublin in the years $1981-2010$ and in the years $1951-1980\left(\right.$ in $\left.{ }^{\circ} \mathrm{C}\right)$

\begin{tabular}{|c|c|c|c|c|r|r|r|r|r|c|c|c|c|}
\hline Okres & I & II & III & IV & V & VI & VII & VIII & IX & X & XI & XII & Rok \\
\hline $1981-2010$ & $-2,0$ & $-1,1$ & 2,8 & 9,1 & 14,7 & 17,4 & 19,5 & 18,7 & 13,7 & 8,7 & 3,3 & $-0,7$ & 8,7 \\
\hline $1951-1980$ & $-3,6$ & $-2,6$ & 1,3 & 8,0 & 13,5 & 17,4 & 18,6 & 17,7 & 13,4 & 8,3 & 3,3 & $-1,0$ & 7,9 \\
\hline Różnica & 1,6 & 1,5 & 1,5 & 1,1 & 1,2 & 0,0 & 0,9 & 1,0 & 0,3 & 0,4 & 0,0 & 0,3 & 0,8 \\
\hline
\end{tabular}


Tabela 2. Najwyższe miesięczne i roczne temperatury powietrza w Lublinie w latach 19812010 i w latach $1951-1980\left(\mathrm{w}^{\circ} \mathrm{C}\right)$

Table 2. The highest mean monthly values and mean annual values of air temperature in Lublin in the years $1981-2010$ and in the years $1951-1980$ (in ${ }^{\circ} \mathrm{C}$ )

\begin{tabular}{|c|c|c|c|c|r|r|r|r|c|c|c|c|c|}
\hline Okres & I & II & III & IV & \multicolumn{1}{|c|}{ V } & VI & VII & VIII & IX & X & XI & XII & Rok \\
\hline $1981-2010$ & 3,1 & 4,8 & 7,1 & 12,8 & 18,0 & 19,5 & 23,5 & 22,3 & 16,3 & 11,7 & 7,2 & 3,6 & 10,0 \\
\hline $1951-1980$ & 2,5 & 2,5 & 5,6 & 11,2 & 16,6 & 21,2 & 21,5 & 20,1 & 16,9 & 11,8 & 6,6 & 3,1 & 9,2 \\
\hline Różnica & 0,6 & 1,7 & 1,5 & 1,6 & 1,4 & $-1,7$ & 2,0 & 2,2 & $-0,6$ & $-0,1$ & 0,6 & 0,5 & 0,8 \\
\hline
\end{tabular}

Tabela 3. Najniższe miesięczne i roczne temperatury powietrza w Lublinie w latach 1981-2010 i w latach $1951-1980\left(\mathrm{w}^{\circ} \mathrm{C}\right)$

Table 3. The lowest mean monthly values and mean annual values of air temperature in Lublin in the years $1981-2010$ and in the years $1951-1980$ (in ${ }^{\circ} \mathrm{C}$ )

\begin{tabular}{|c|r|r|r|c|r|c|r|c|c|c|c|c|c|}
\hline Okres & \multicolumn{1}{|c|}{ I } & \multicolumn{1}{c|}{ II } & III & IV & \multicolumn{1}{c|}{ V } & VI & VII & VIII & IX & X & XI & XII & Rok \\
\hline $1981-2010$ & $-12,2$ & $-9,5$ & $-2,6$ & 5,4 & 11,3 & 14,8 & 16,2 & 15,3 & 10,5 & 5,9 & $-2,7$ & $-6,3$ & 6,7 \\
\hline $1951-1980$ & $-12,2$ & $-13,0$ & $-4,4$ & 4,6 & 10,3 & 14,9 & 15,5 & 15,9 & 11,1 & 5,4 & $-1,2$ & $-8,0$ & 6,1 \\
\hline Różnica & 0,0 & 3,5 & 1,8 & 0,8 & 1,0 & $-0,1$ & 0,7 & $-0,6$ & $-0,6$ & 0,5 & $-1,5$ & 1,7 & 0,6 \\
\hline
\end{tabular}

i wartość najniższa $15,3^{\circ} \mathrm{C}$. Tym samym zakres temperatury w tym miesiącu w latach $1981-2010$ wyniós $77^{\circ} \mathrm{C}$ w porównaniu z $4,2^{\circ} \mathrm{C}$ w okresie $1951-1980$. Zwiększył się także zakres występowania średniej miesięcznej temperatury w styczniu o $0,6^{\circ} \mathrm{C}$.

Temperatura średnia dobowa zmieniała się od $-22,8^{\circ} \mathrm{C}$ ( 8 stycznia $1987 \mathrm{r}$.) do 28,7 $\mathrm{C}$ (13 lipca 1959 r.) (Tab. 4). Zakres zmienności średniej dobowej temperatury powietrza wyniósł zatem $51,5^{\circ} \mathrm{C}$. Dla porównania, w Warszawie zakres zmienności temperatury średniej dobowej w latach 1947-2013 był większy i wyniósł 53,7 $\mathrm{C}$ (Kossowska-Cezak, Wawer 2014).

Największą rozpiętością średniej dobowej temperatury cechuje się luty $33,1^{\circ} \mathrm{C}$, a najmniejszą lipiec $18,4^{\circ} \mathrm{C}$. Ujemne wartości średniej dobowej wystąpiły w Lublinie w okresie od 31 października do 1 kwietnia.

Wartości najwyższe średniej dobowej notowano głównie w okresie 19812010 (w 6 miesiącach). W dwu miesiącach, w sierpniu i grudniu najwyższe wartości średniej dobowej wystąpiły w obu analizowanych okresach. Wartości najniższe notowane były głównie (w 8 miesiącach roku) w latach 1951-1980.

\section{CZĘSTOŚĆ WYSTĘPOWANIA ŚREDNIEJ TEMPERATURY DOBOWEJ W PRZEDZIAŁACH 2-STOPNIOWYCH W LATACH 1951-1980 I 1981-2010}

Rozkład liczby dni w roku w Lublinie ze średnią dobową temperaturą powietrza w latach 1951-1980 w przedziałach 2-stopniowych cechuje się maksi- 
Tabela 4. Najwyższe i najniższe wartości średniej dobowej temperatury powietrza w Lublinie w latach $1951-2010\left(\mathrm{w}^{\circ} \mathrm{C}\right)$

Table 4 . The highest and the lowest mean daily values of air temperature in Lublin in the years $1951-2010\left(\right.$ in $\left.{ }^{\circ} \mathrm{C}\right)$

\begin{tabular}{|c|c|c|c|c|c|c|c|c|c|c|c|c|c|}
\hline & I & II & III & IV & V & VI & VII & VIII & IX & $\mathrm{X}$ & XI & XII & Rok \\
\hline $\begin{array}{c}\text { Wartośćć } \\
\text { najwyż- } \\
\text { sza }\end{array}$ & 9,6 & 11,2 & 15,9 & 21,0 & 25,9 & \begin{tabular}{|l|}
27,1 \\
\end{tabular} & \begin{tabular}{|l|}
28,7 \\
\end{tabular} & 28,1 & 23,3 & 18,6 & 15,0 & 11,2 & 28,7 \\
\hline Data & $29 ` 02$ & $\begin{array}{l}25 ` 89 \\
26 ` 90 \\
\end{array}$ & 2174 & $30 ` 77$ & $30 ` 05$ & $28 ` 63$ & $13 ` 59$ & $\begin{array}{l}15 ` 54 \\
10 ` 92 \\
\end{array}$ & $\begin{array}{l}584 \\
6 ` 08 \\
\end{array}$ & 3`01 & 8`97 & $\begin{array}{c}5 ` 61 \\
19 ` 89\end{array}$ & $13 ` 59$ \\
\hline $\begin{array}{l}\text { Wartość } \\
\text { najniż- } \\
\text { sza }\end{array}$ & $-22,8$ & $-21,9$ & $-15,3$ & $-3,1$ & 1,0 & 4,4 & 10,3 & 9,6 & 2,7 & $-2,6$ & $-12,6$ & $-20,1$ & $-22,8$ \\
\hline Data & 8`87 & $1 ` 56$ & $3 ` 87$ & $1 ` 58$ & $\begin{array}{c}1 ` 62 \\
11 ` 78 \\
\end{array}$ & 6`62 & 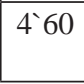 & $28^{\prime} 81$ & $30 ` 93$ & $31 ` 66$ & \begin{tabular}{|l|l}
$17^{\prime} 65$ \\
$18^{`} 65$ \\
\end{tabular} & $31 ` 69$ & $8 ` 87$ \\
\hline
\end{tabular}

mum wynoszącym ok. 33 dni, które przypada na przedział $0,1-2,0^{\circ} \mathrm{C}$ (Tab. 5). Maksimum drugorzędne - prawie 30 dni przypada na przedziały: $16,1-18,0^{\circ} \mathrm{C}$ i $14,1-16,0^{\circ} \mathrm{C}$. Najczęstsze w tym 30-leciu dni z temperaturą średnią dobową występują w przedziale $0,1-2,0^{\circ} \mathrm{C}$ od października do maja. W miesiącach XII-III są one najczęstsze, z maksimum w grudniu - średnio ok.7 dni. Dni ze średnią dobową $16,1-18,0^{\circ} \mathrm{C}$, notowane od kwietnia do października, są najczęstsze w lipcu i sierpniu. W tym ostatnim miesiącu ich udział wynosi blisko 8 dni. Natomiast niewiele rzadziej występujące dni z temperaturą $14,1-16,0^{\circ} \mathrm{C}$ notowane od marca do listopada $\mathrm{w}$ żadnym $\mathrm{z}$ tych miesięcy nie są najczęstsze.

Rozkład liczby dni w roku w przedziałach 2-stopniowych w latach 19812010 jest podobny do rozkładu takich dni w latach 1951-1980, chociaż zmniejszyły się różnice między liczbą dni w przedziale $0,1-2,0^{\circ} \mathrm{C}$, a liczbą takich dni w przedziale $16,1-18,0^{\circ} \mathrm{C}$ (Tab. 6).

Zmieniły się natomiast, aż w 6 miesiącach, maksymalne częstości dni ze średnią dobową. Największe zmiany (przesunięcie o dwa przedziały w stronę wyższych wartości) zaszły w kwietniu, maju i listopadzie. W lipcu i sierpniu maksymalna częstość dni notowana jest w przedziale $18.1-20.0^{\circ} \mathrm{C}$, podczas gdy w okresie poprzednim $\mathrm{w}$ przedziale $16,1-18,0$.W przypadku czerwca maksimum liczby dni występuje w przedziale $12.1-14.0^{\circ} \mathrm{C}$, a wcześniej w przedziale $16,1-18,0^{\circ} \mathrm{C}$.

W Tab. 7 zamieszczono różnice w średniej liczbie dni w przedziałach między latami 1981-2010 i 1951-1980 w miesiącach i roku. Jak można zauważyć największy przyrost liczby dni w roku ( o blisko 3 dni) dotyczy przedziału 10,1$12,0^{\circ} \mathrm{C}$ i przedziału $22,1-24,0^{\circ} \mathrm{C}$. Łączny przyrost liczby dni z temperaturą powyżej $10,0^{\circ} \mathrm{C}$ wyniósł blisko 12 dni. Jednocześnie o ok. 10 zmniejszyła się liczba dni ze średnią poniżej $0^{\circ} \mathrm{C}$. 
Tabela 5. Przeciętna liczba dni ze średnią dobową temperaturą powietrza w przedziałach 2-stopniowych w Lublinie w latach 1951-1980

Table 5. The average numbers of days with mean daily air temperature in 2-degree intervals in Lublin in the years 1951-1980

\begin{tabular}{|c|c|c|c|c|c|c|c|c|c|c|c|c|c|}
\hline $\begin{array}{c}\text { Temperatura } \\
\left({ }^{\circ} \mathrm{C}\right)\end{array}$ & I & II & III & IV & V & VI & VII & VIII & IX & X & XI & XII & Rok \\
\hline $28,1-30,0$ & & & & & & & 0,0 & 0,0 & & & & & 0,1 \\
\hline $26,1-28,0$ & & & & & & 0,1 & 0,2 & 0,3 & & & & & 0,6 \\
\hline $24,1-26,0$ & & & & & 0,1 & 0,6 & 1,3 & 0,6 & & & & & 2,7 \\
\hline $22,1-24,0$ & & & & & 0,6 & 2,2 & 3,2 & 1,9 & 0,1 & & & & 7,9 \\
\hline $20,1-22,0$ & & & & 0,1 & 1,4 & 4,7 & 5,5 & 4,2 & 0,9 & & & & 16,8 \\
\hline $18,1-20,0$ & & & & 0,5 & 2,4 & 6,1 & 6,5 & 6,5 & 2,9 & & & & 24,9 \\
\hline $16,1-18,0$ & & & & 0,7 & 4,4 & 6,0 & 6,7 & 7,5 & 3,8 & 0,6 & & & 29,7 \\
\hline $14,1-16,0$ & & & 0,1 & 1,8 & 4,7 & 4,7 & 5,4 & 6,1 & 4,9 & 1,7 & 0,1 & & 29,5 \\
\hline $12,1-14,0$ & & & 0,2 & 2,6 & 6,1 & 3,2 & 2,0 & 3,3 & 5,8 & 2,5 & 0,2 & & 25,8 \\
\hline $10,1-12,0$ & & 0,0 & 0,6 & 3,2 & 4,5 & 1,7 & 0,2 & 0,6 & 5,8 & 4,9 & 1,1 & 0,1 & 22,7 \\
\hline $8,1-10,0$ & & 0,1 & 1,6 & 5,0 & 3,6 & 0,5 & & 0,1 & 3,7 & 6,6 & 2,9 & 0,2 & 24,1 \\
\hline $6,1-8,0$ & 0,0 & 0,3 & 2,9 & 5,1 & 1,8 & 0,2 & & & 1,7 & 6,3 & 4,1 & 1,1 & 23,4 \\
\hline $4,1-6,0$ & 0,6 & 1,4 & 3,4 & 4,8 & 1,0 & 0,1 & & & 0,4 & 4,5 & 4,2 & 2,3 & 22,7 \\
\hline $2,1-4,0$ & 2,8 & 3,1 & 4,7 & 3,7 & 0,3 & & & & 0,1 & 2,4 & 5,8 & 4,1 & 26,9 \\
\hline $0,1-2,0$ & 5,5 & 5,4 & 6,1 & 2,0 & 0,1 & & & & & 1,1 & 5,3 & 7,3 & 32,8 \\
\hline$-1,9-0,0$ & 5,1 & 4,2 & 4,1 & 0,4 & & & & & & 0,4 & 3,5 & 5,3 & 23,1 \\
\hline$-3,9--2,0$ & 4,1 & 4,0 & 2,9 & 0,0 & & & & & & & 1,6 & 3,8 & 16,4 \\
\hline$-5,9--4,0$ & 3,5 & 3,1 & 2,7 & & & & & & & 0,0 & 0,8 & 2,6 & 12,8 \\
\hline$-7,9--6,0$ & 3,1 & 2,1 & 1,3 & & & & & & & & 0,3 & 1,5 & 8,3 \\
\hline$-9,9--8,0$ & 2,3 & 1,4 & 0,1 & & & & & & & & 0,1 & 0,9 & 4,9 \\
\hline$-11,9--10,0$ & 1,5 & 1,2 & 0,2 & & & & & & & & 0,0 & 0,8 & 3,7 \\
\hline$-13,9--12,0$ & 1,2 & 0,8 & 0,1 & & & & & & & & 0,1 & 0,5 & 2,7 \\
\hline$-15,9--14,0$ & 0,5 & 0,5 & 0,0 & & & & & & & & & 0,1 & 1,2 \\
\hline$-17,9--16,0$ & 0,3 & 0,3 & & & & & & & & & & 0,2 & 0,8 \\
\hline$-19,9--18,0$ & 0,3 & 0,1 & & & & & & & & & & 0,1 & 0,5 \\
\hline$-21,9--20,0$ & 0,2 & 0,1 & & & & & & & & & & 0,0 & 0,3 \\
\hline$-23,9--22,0$ & 0,0 & & & & & & & & & & & & 0,0 \\
\hline & 31 & 28,3 & 31 & 30 & 31 & 30 & 31 & 31 & 30 & 31 & 30 & 31 & 365,3 \\
\hline
\end{tabular}

W przebiegu rocznym praktycznie w każdym miesiącu nastąpił przyrost liczby dni w przedziałach o najwyższych wartościach dla danego miesiąca. Np. w styczniu i lutym w okresie późniejszym notowano odpowiednio, o 4 i 3 dni więcej z temperaturą średnią dobową powyżej 2,0 $\mathrm{C}$ niż w latach 1951-1980. Jednocześnie zmniejszyła się liczba dni z ujemnymi temperaturami w styczniu, o 5 dni, a w lutym o ponad 3 dni. W sierpniu przybyło dni z temperaturą powyżej $18,1^{\circ} \mathrm{C}$, łącznie o blisko 5 dni. 
Tabela 6. Przeciętna liczba dni ze średnią dobową temperaturą powietrza w przedziałach 2-stopniowych w Lublinie w latach 1981-2010

Table 6 . The average numbers of days with mean daily air temperature in 2-degree intervals in Lublin in the years 1981-2010

\begin{tabular}{|c|c|c|c|c|c|c|c|c|c|c|c|c|c|}
\hline $\begin{array}{c}\text { Temperatura } \\
(\mathrm{oC})\end{array}$ & I & II & III & IV & V & VI & VII & VIII & IX & X & XI & XII & Rok \\
\hline $28,1-30,0$ & & & & & & & 0,1 & 0,0 & & & & & 0,1 \\
\hline $26,1-28,0$ & & & & & & 0,0 & 0,9 & 0,4 & & & & & 1,3 \\
\hline $24,1-26,0$ & & & & & 0,2 & 0,9 & 2,1 & 1,3 & & & & & 4,4 \\
\hline $22,1-24,0$ & & & & & 0,7 & 2,2 & 4,4 & 3,0 & 0,1 & & & & 10,4 \\
\hline $20,1-22,0$ & & & & 0,1 & 1,6 & 3,8 & 5,9 & 5,8 & 0,9 & & & & 18,1 \\
\hline $18,1-20,0$ & & & & 0,7 & 3,2 & 5,9 & 6,6 & 7,7 & 2,4 & & & & 26,6 \\
\hline $16,1-18,0$ & & & & 1,1 & 6,2 & 5,6 & 5,9 & 6,2 & 4,6 & 0,8 & & & 30,4 \\
\hline $14,1-16,0$ & & & 0,0 & 2,5 & 5,9 & 6,0 & 3,4 & 4,1 & 5,1 & 2,5 & 0,1 & & 29,6 \\
\hline $12,1-14,0$ & & & 0,4 & 2,8 & 5,1 & 3,9 & 1,4 & 2,0 & 6,5 & 3,7 & 0,3 & & 26,0 \\
\hline $10,1-12,0$ & & 0,2 & 1,0 & 5,4 & 4,2 & 1,5 & 0,4 & 0,4 & 6,0 & 5,1 & 1,1 & 0,1 & 25,5 \\
\hline $8,1-10,0$ & & 0,5 & 2,8 & 5,3 & 2,7 & 0,2 & & 0,1 & 3,2 & 5,8 & 2,6 & 0,4 & 23,9 \\
\hline $6,1-8,0$ & 0,8 & 1,1 & 3,7 & 5,1 & 0,8 & & & & 1,0 & 4,7 & 5,0 & 1,2 & 23,4 \\
\hline $4,1-6,0$ & 2,3 & 2,1 & 4,5 & 2,7 & 0,2 & & & & 0,2 & 4,1 & 4,6 & 2,3 & 23,1 \\
\hline $2,1-4,0$ & 4,5 & 3,5 & 4,1 & 2,6 & 0,1 & & & & 0,0 & 2,5 & 4,2 & 4,9 & 26,4 \\
\hline $0,1-2,0$ & 5,5 & 5,2 & 6,6 & 1,4 & & & & & & 1,2 & 4,7 & 6,3 & 31,0 \\
\hline$-1,9-0,0$ & 4,2 & 4,4 & 4,2 & 0,4 & & & & & & 0,6 & 3,4 & 5,4 & 22,5 \\
\hline$-3,9--2,0$ & 3,7 & 3,6 & 1,7 & 0,0 & & & & & & 0,0 & 2,2 & 3,5 & 14,7 \\
\hline$-5,9--4,0$ & 3,1 & 2,9 & 1,3 & & & & & & & & 0,9 & 2,9 & 11,1 \\
\hline$-7,9--6,0$ & 2,0 & 2,0 & 0,5 & & & & & & & & 0,4 & 1,4 & 6,2 \\
\hline$-9,9--8,0$ & 1,4 & 1,2 & 0,2 & & & & & & & & 0,2 & 1,1 & 4,2 \\
\hline$-11,9--10,0$ & 1,2 & 0,7 & 0,1 & & & & & & & & 0,1 & 0,5 & 2,6 \\
\hline$-13,9--12,0$ & 0,8 & 0,4 & & & & & & & & & & 0,5 & 1,6 \\
\hline$-15,9--14,0$ & 0,4 & 0,2 & 0,1 & & & & & & & & & 0,2 & 0,9 \\
\hline$-17,9--16,0$ & 0,5 & 0,1 & & & & & & & & & & 0,1 & 0,7 \\
\hline$-19,9--18,0$ & 0,2 & 0,0 & & & & & & & & & & 0,1 & 0,3 \\
\hline$-21,9--20,0$ & 0,2 & 0,0 & & & & & & & & & & & 0,3 \\
\hline$-23,9--22,0$ & 0,0 & & & & & & & & & & & & 0,0 \\
\hline & 31 & 28,2 & 31 & 30 & 31 & 30 & 31 & 31 & 30 & 31 & 30 & 31 & 365,2 \\
\hline
\end{tabular}

\section{CZĘSTOŚĆ WYSTĘPOWANIA ŚREDNIEJ TEMPERATURY DOBOWEJ W PRZEDZIAŁACH 5-STOPNIOWYCH \\ W LATACH 1951-1980 I 1981-2010}

Rozkład liczby dni w roku w Lublinie ze średnią dobową temperaturą powietrza w przedziałach 5-stopniowych w latach 1951-1980 cechuje się maksimum wynoszącym prawie 71 dni, które przypada na przedział $0,1-5,0^{\circ} \mathrm{C}$ (Tab. 8). Mak- 
Tabela 7. Różnice liczby dni ze średnią dobową temperaturą powietrza w przedziałach 2-stopniowych między latami: 1981-2010 i 1951-1980 w Lublinie

Table 7. The differences in the number of days with mean daily air temperature in 2-degree intervals in Lublin between the years 1981-2010 and 1951-1980

\begin{tabular}{|c|r|r|r|r|r|r|r|r|r|r|r|r|r|}
\hline $\begin{array}{c}\text { Temperatura } \\
(\mathrm{oC})\end{array}$ & I & II & III & IV & V & VI & VII & VIII & IX & X & XI & XII & Rok \\
\hline $28,1-30,0$ & & & & & & & 0,0 & 0,0 & & & & & 0,0 \\
\hline $26,1-28,0$ & & & & & & $-0,1$ & 0,7 & 0,1 & & & & & 0,7 \\
\hline $24,1-26,0$ & & & & & 0,2 & 0,2 & 0,7 & 0,6 & & & & & 1,8 \\
\hline $22,1-24,0$ & & & & & 0,1 & 0,0 & 1,2 & 1,1 & 0,0 & & & & 2,5 \\
\hline $20,1-22,0$ & & & & 0 & 0,2 & $-0,9$ & 0,4 & 1,6 & 0,0 & & & & 1,3 \\
\hline $18,1-20,0$ & & & & 0,2 & 0,8 & $-0,2$ & 0,1 & 1,2 & $-0,5$ & & & & 1,7 \\
\hline $16,1-18,0$ & & & & 0,4 & 1,8 & $-0,3$ & $-0,8$ & $-1,3$ & 0,7 & 0,2 & & & 0,7 \\
\hline $14,1-16,0$ & & & $-0,1$ & 0,7 & 1,2 & 1,3 & $-2,0$ & $-2,0$ & 0,2 & 0,7 & 0,1 & & 0,2 \\
\hline $12,1-14,0$ & & & 0,2 & 0,2 & $-1,0$ & 0,7 & $-0,6$ & $-1,3$ & 0,7 & 1,2 & 0,1 & & 0,2 \\
\hline $10,1-12,0$ & & 0,1 & 0,4 & 2,2 & $-0,3$ & $-0,2$ & 0,2 & $-0,2$ & 0,2 & 0,3 & 0,0 & 0,0 & 2,8 \\
\hline $8,1-10,0$ & & 0,5 & 1,2 & 0,3 & $-0,9$ & $-0,3$ & & 0,1 & $-0,5$ & $-0,8$ & $-0,3$ & 0,2 & $-0,3$ \\
\hline $6,1-8,0$ & 0,7 & 0,8 & 0,8 & 0,0 & $-0,9$ & & & & $-0,6$ & $-1,6$ & 0,9 & 0,1 & $-0,1$ \\
\hline $4,1-6,0$ & 1,7 & 0,7 & 1,1 & $-2,1$ & $-0,8$ & & & & $-0,2$ & $-0,4$ & 0,4 & 0,0 & 0,4 \\
\hline $2,1-4,0$ & 1,6 & 0,5 & $-0,6$ & $-1,2$ & $-0,3$ & & & & 0,0 & 0,1 & $-1,5$ & 0,9 & $-0,5$ \\
\hline $0,1-2,0$ & 0,0 & $-0,2$ & 0,5 & $-0,6$ & & & & & & 0,1 & $-0,6$ & $-1,0$ & $-1,8$ \\
\hline$-1,9-0,0$ & $-0,8$ & 0,1 & 0,1 & 0,0 & & & & & & 0,2 & $-0,1$ & 0,1 & $-0,6$ \\
\hline$-3,9--2,0$ & $-0,4$ & $-0,4$ & $-1,2$ & 0,0 & & & & & & 0,0 & 0,6 & $-0,3$ & $-1,7$ \\
\hline$-5,9--4,0$ & $-0,4$ & $-0,2$ & $-1,4$ & & & & & & & & 0,1 & 0,2 & $-1,7$ \\
\hline$-7,9--6,0$ & $-1,1$ & $-0,2$ & $-0,8$ & & & & & & & & 0,1 & 0,0 & $-2,0$ \\
\hline$-9,9--8,0$ & $-0,9$ & $-0,2$ & 0,1 & & & & & & & & 0,1 & 0,2 & $-0,7$ \\
\hline$-11,9--10,0$ & $-0,3$ & $-0,5$ & $-0,1$ & & & & & & & & 0,1 & $-0,3$ & $-1,1$ \\
\hline$-13,9--12,0$ & $-0,5$ & $-0,4$ & & & & & & & & & & 0,0 & $-1,1$ \\
\hline$-15,9--14,0$ & $-0,1$ & $-0,3$ & 0,0 & & & & & & & & & 0,1 & $-0,3$ \\
\hline$-17,9--16,0$ & 0,1 & $-0,2$ & & & & & & & & & & $-0,1$ & $-0,2$ \\
\hline$-19,9--18,0$ & $-0,1$ & $-0,1$ & & & & & & & & & & 0,0 & $-0,2$ \\
\hline$-21,9--20,0$ & 0,1 & $-0,1$ & & & & & & & & & & & 0,0 \\
\hline$-23,9--22,0$ & 0,0 & & & & & & & & & & & & 0,0 \\
\hline
\end{tabular}

simum drugorzędne - ponad 69 dni przypada na przedział: $15,1-20,0^{\circ} \mathrm{C}$. Najczęstsze w tym 30 -leciu temperatury o średniej $0,1-5,0^{\circ} \mathrm{C}$ występują od września do maja. W miesiącach: kwiecień, listopad i grudzień są one najczęstsze, z maksimum w listopadzie - średnio ok. 13 dni. Dni ze średnią dobową temperaturą powietrza w przedziałach $15,1-20,0^{\circ} \mathrm{C}$, notowane od kwietnia do października, są najczęstsze w czerwcu, lipcu i sierpniu. W tym ostatnim miesiącu ich udział wynosi ponad $17 \mathrm{dni}$. Średnie temperatury w przedziale $5,1-10,0^{\circ} \mathrm{C}$ nie były notowane tylko w lipcu. 
Tabela 8. Przeciętna liczba dni z temperaturą średnią dobową w przedziałach 5-stopniowych w Lublinie w latach 1951-1980

Table 8 . The average numbers of days with mean daily air temperature in 5-degree intervals in Lublin in the years 1951-1980

\begin{tabular}{|c|c|r|r|r|r|r|r|r|r|r|r|r|r|}
\hline $\begin{array}{c}\text { Temperatura } \\
\left({ }^{\circ} \mathrm{C}\right)\end{array}$ & I & II & III & IV & V & VI & VII & VIII & IX & X & XI & XII & Rok \\
\hline $25,1-30,0$ & & & & & & 0,4 & 0,7 & 0,6 & & & & & 1,7 \\
\hline $20,1-25,0$ & & & & 0,1 & 2,1 & 7,3 & 9,5 & 6,6 & 1,0 & & & & 26,5 \\
\hline $15,1-20,0$ & & & & 2,3 & 9,1 & 14,2 & 16,3 & 17,2 & 9,0 & 1,3 & & & 69,4 \\
\hline $10,1-15,0$ & & & 0,9 & 6,6 & 13,0 & 7,4 & 4,5 & 6,6 & 14,2 & 8,4 & 1,3 & 0,1 & 63,0 \\
\hline $5,1-10,0$ & 0,3 & 1,1 & 5,9 & 12,1 & 6,0 & 0,7 & & 0,1 & 5,7 & 15,6 & 9,0 & 2,1 & 58,6 \\
\hline $0,1-5,0$ & 8,7 & 9,2 & 12,5 & 8,5 & 0,8 & & & & 0,2 & 5,2 & 13,3 & 12,4 & 70,9 \\
\hline$-4,9--0,0$ & 10,9 & 10,1 & 8,7 & 0,4 & & & & & & 0,4 & 5,5 & 10,7 & 46,8 \\
\hline$-9,9--5,0$ & 7,1 & 4,8 & 2,6 & & & & & & & & 0,7 & 3,5 & 18,7 \\
\hline$-14,9--10,0$ & 3,0 & 2,4 & 0,3 & & & & & & & & 0,1 & 1,8 & 7,6 \\
\hline$-19,9--15,0$ & 0,8 & 0,5 & & & & & & & & & & 0,4 & 1,7 \\
\hline$-24,9--20,0$ & 0,2 & 0,1 & & & & & & & & & & & 0,3 \\
\hline & 31,0 & 28,3 & 31,0 & 30,0 & 31,0 & 30,0 & 31,0 & 31,0 & 30,0 & 31,0 & 30,0 & 31,0 & 365,3 \\
\hline
\end{tabular}

Rozkład liczby dni w roku w przedziałach 5-stopniowych w latach 1981-2010 nieco różni się od rozkładu takich dni w latach 1951-1980 (Tab. 9). Główne maksimum liczby dni występuje w przedziale $15,1-20,0^{\circ} \mathrm{C}-71 \mathrm{dni}$, a drugorzędne w przedziale $0,1-5,0^{\circ} \mathrm{C}$, poniżej 70 dni. Aż o 6 dni średnio w roku wzrosła liczba dni powyżej $20,0^{\circ} \mathrm{C}$. Jednocześnie liczba dni z temperaturą $\leq 0^{\circ} \mathrm{C}$ zmniejszyła się o 10 . W przebiegu rocznym największe zmiany w rozkładzie liczby dni z temperaturą $\mathrm{w}$ poszczególnych przedziałach zaszły $\mathrm{w}$ dwóch miesiącach: styczniu i lutym. W miesiącach tych maksymalna liczba dni była notowana w przedziale $0,1-5,0^{\circ} \mathrm{C}$, podczas gdy w okresie wcześniejszym w przedziale $-4,0-0,0^{\circ} \mathrm{C}$.

Jak można zauważyć z Tab.10, największy przyrost liczby dni w roku (po ok. 4 dni) występuje w przedziale $20,1-25,0^{\circ} \mathrm{C}$ i przedziale $10.1-15,0^{\circ} \mathrm{C}$.W przebiegu rocznym praktycznie w każdym miesiącu (tak jak w przypadku przedziałów 2-stopniowych) nastąpił przyrost liczby dni w przedziałach o najwyższych wartościach dla danego miesiąca. Np. w styczniu i w marcu w okresie późniejszym notowano po ok. 4 dni więcej z temperaturą średnią dobową powyżej $0,0^{\circ} \mathrm{C}$ niż w latach 1951-1980, a lipcu i sierpniu po 3 dni więcej z temperaturą powyżej $20,0^{\circ} \mathrm{C}$. Jak wykazała analiza liczby dni z temperaturą powyżej $20,0^{\circ} \mathrm{C}$ przyrost tych dni największy był, podobnie jak w Warszawie (Kossowska-Cezak, Wawer 2014), w pierwszej dekadzie XXI wieku. Jednocześnie aż o 3 dni $\mathrm{w}$ miesiącu zmniejszyła się liczba dni w przedziale $0,1-5,0^{\circ} \mathrm{C}$ w kwietniu i $5,1-$ $10^{\circ} \mathrm{C}$ w październiku. 
Tabela 9. Przeciętna liczba dni z temperaturą średnią dobową w przedziałach 5-stopniowych w Lublinie w latach 1981-2010

Table 9 . The average numbers of days with mean daily air temperature in 5-degree intervals in Lublin in the years 1981-2010

\begin{tabular}{|c|r|r|r|r|r|r|r|r|r|r|r|r|r|}
\hline $\begin{array}{c}\text { Temperatura } \\
(\mathrm{oC})\end{array}$ & I & II & III & IV & V & VI & VII & VIII & IX & X & XI & XII & Rok \\
\hline $25,1-30,0$ & & & & & & 0,4 & 2,0 & 1,0 & & & & & 3,5 \\
\hline $20,1-25,0$ & & & & 0,1 & 2,5 & 6,5 & 11,3 & 9,4 & 1,0 & & & & 30,8 \\
\hline $15,1-20,0$ & & & & 2,9 & 12,2 & 14,4 & 14,5 & 16,4 & 9,0 & 1,7 & & & 71,1 \\
\hline $10,1-15,0$ & & & 1,4 & 9,6 & 12,4 & 8,5 & 3,2 & 4,1 & 15,5 & 10,4 & 1,6 & 0,1 & 67,0 \\
\hline $5,1-10,0$ & 2,1 & 2,6 & 8,4 & 11,8 & 3,73 & 0,2 & & 0,1 & 4,4 & 12,6 & 9,8 & 2,4 & 58,0 \\
\hline $0,1-5,0$ & 11,3 & 10,0 & 13,3 & 5,2 & 0,1 & & & & 0,0 & 5,7 & 11,4 & 12,6 & 69,6 \\
\hline$-4,9--0,0$ & 9,4 & 9,6 & 6,5 & 0,4 & & & & & & 0,6 & 6,2 & 10,7 & 43,4 \\
\hline$-9,9--5,0$ & 5,0 & 4,4 & 1,3 & & & & & & & & 0,9 & 3,8 & 15,5 \\
\hline$-14,9--10,0$ & 2,2 & 1,3 & 0,1 & & & & & & & & 0,1 & 1,1 & 4,8 \\
\hline$-19,9--15,0$ & 0,7 & 0,2 & & & & & & & & & & 0,2 & 1,2 \\
\hline$-24,9--20,0$ & 0,3 & 0,0 & & & & & & & & & & & 0,3 \\
\hline & 31,0 & 28,2 & 31,0 & 30,0 & 31,0 & 30,0 & 31,0 & 31,0 & 30,0 & 31,0 & 30,0 & 31,0 & 365,2 \\
\hline
\end{tabular}

Tabela10. Różnice liczby dni ze średnią dobową temperatura powietrza w przedziałach 5-stopniowych między latami: 1981-2010 i 1951-1980

Table 10. The differences in number of days with mean daily air temperature in 5-degree intervals in Lublin between the years 1981-2010 and 1951-1980

\begin{tabular}{|c|r|r|r|r|r|r|r|r|r|r|r|r|r|}
\hline & I & II & III & IV & V & VI & VII & VIII & IX & X & XI & XII & Rok \\
\hline $25,1-30,0$ & & & & & & & 1,3 & 0,4 & & & & & 1,8 \\
\hline $20,1-25,0$ & & & & & 0,4 & $-0,8$ & 1,7 & 2,8 & 0,1 & & & & 4,2 \\
\hline $15,1-20,0$ & & & & 0,6 & 3,1 & 0,3 & $-1,8$ & $-0,8$ & 0,0 & 0,4 & & & 1,8 \\
\hline $10,1-15,0$ & & & 0,5 & 3,0 & $-0,6$ & 1,1 & $-1,3$ & $-2,5$ & 1,3 & 2,0 & 0,2 & & 4,0 \\
\hline $5,1-10,0$ & 1,7 & 1,5 & 2,5 & $-0,3$ & $-2,3$ & $-0,5$ & & 0,1 & $-1,3$ & $-3,0$ & 0,8 & 0,3 & $-0,6$ \\
\hline $0,1-5,0$ & 2,6 & 0,7 & 0,7 & $-3,3$ & $-0,7$ & & & & $-0,1$ & 0,5 & $-2,0$ & 0,2 & $-1,3$ \\
\hline$-4,9--0,0$ & $-1,5$ & $-0,5$ & $-2,2$ & & & & & & & 0,2 & 0,7 & $-0,1$ & $-3,4$ \\
\hline$-9,9--5,0$ & $-2,1$ & $-0,4$ & $-1,3$ & & & & & & & & 0,2 & 0,4 & $-3,2$ \\
\hline$-14,9--10,0$ & $-0,8$ & $-1,1$ & $-0,2$ & & & & & & & & & $-0,6$ & $-2,8$ \\
\hline$-19,9--15,0$ & $-0,1$ & $-0,3$ & & & & & & & & & & $-0,2$ & $-0,5$ \\
\hline$-24,9--20,0$ & 0,1 & $-0,1$ & & & & & & & & & & & 0,0 \\
\hline
\end{tabular}

\section{WNIOSKI}

Średnia temperatura powietrza w Lublinie w latach 1981-2010 była wyższa o $0,8^{\circ} \mathrm{C}$ w porównaniu z okresem $1951-1980$. Największy wzrost temperatury w okresie późniejszym w stosunku do lat 1951-1980 wystąpił w styczniu, lutym i marcu odpowiednio: $1,6^{\circ} \mathrm{C}, 1,5^{\circ} \mathrm{C}$ i $1,5^{\circ} \mathrm{C}$. Średnia temperatura powietrza nie 
uległa zmianie w czerwcu i listopadzie.W sześciu miesiącach nastąpił wzrost zarówno najwyższych, jak i najniższych średnich miesięcznych. W styczniu i sierpniu nastąpiło zwiększenie zakresu temperatury średniej miesięcznej. W przypadku przedziałów 2-stopniowych największa częstość dni w obu okresach występuje w przedziale $0,1-2,0^{\circ} \mathrm{C}$-odpowiednio 33 i 31 dni.

$\mathrm{W}$ przebiegu rocznym w kilku miesiącach nastąpiły zmiany w przedziałach o największej częstości. W kwietniu, maju i listopadzie maksymalna częstość dni w drugim okresie zmieniła się o dwa przedziały, a w lipcu i sierpniu o jeden przedział.

Porównanie częstości dni w poszczególnych przedziałach 2-stopniowych pokazuje, że w latach 1981-2010 nastąpił wzrost liczby dni ze średnią temperaturą powietrza głównie w przedziale $10,1-12,0^{\circ} \mathrm{C}$ i w przedziale $18,1-26,0^{\circ} \mathrm{C}$. Takich dni jest średnio o 12 więcej. Największy spadek liczby dni zanotowano w przedziale $-7,9--6,0^{\circ} \mathrm{C}$, średnio o ok. 2 dni.

W latach 1951-1980 najczęściej notowana była temperatura w przedziale $0,1-5,0^{\circ} \mathrm{C}-71 \mathrm{dni}$ w roku, oraz w przedziale $15,1-20,0^{\circ} \mathrm{C}-70 \mathrm{dni}$ w roku. W latach 1981-2010 najczęściej notowana była temperatura w przedziale $15,1-20,0^{\circ} \mathrm{C}$ $-71 \mathrm{dni}$ w roku, oraz w przedziale $0,1-5,0^{\circ} \mathrm{C}-70 \mathrm{dni}$ w roku.

W pierwszym analizowanym okresie w styczniu i lutym najczęściej notowane były dni $\mathrm{z}$ temperaturą $\mathrm{w}$ przedziale $-4,9-0,0^{\circ} \mathrm{C}$, a w drugim okresie $\mathrm{w}$ przedziale $0,1-5,0^{\circ} \mathrm{C}$.

Porównanie częstości dni w poszczególnych przedziałach 5-stopniowych pokazuje, że w latach 1981-2010 nastąpił wzrost liczby dni ze średnią temperaturą powietrza powyżej $10,0^{\circ} \mathrm{C}$. Takich dni jest średnio o 12 więcej. Największy spadek liczby dni zanotowano w przedziale $-9,9-0,0^{\circ} \mathrm{C}$, średnio o ok. 7 dni.

$\mathrm{W}$ przebiegu rocznym największe zmiany $\mathrm{w}$ dwu analizowanych okresach obserwuje się w styczniu. W miesiącu tym w latach 1981-2010 nastąpił przyrost liczby dni z temperaturą powyżej $0,0^{\circ} \mathrm{C}$ o 4 dni.

Porównanie uzyskanych wyników z dwóch 30-leci wykazało, że zakres wahań temperatury średniej dobowej w roku nie uległ zmianie (od $-23,9--22,0^{\circ} \mathrm{C}$ do $28,1-30,0^{\circ} \mathrm{C}$ ). Nie zmienił się także zakres wahań temperatury powietrza w poszczególnych miesiącach. Zwiększyła się natomiast wyraźnie liczba dni z temperaturą $>20^{\circ} \mathrm{C}$, średnio o 6 dni w roku a zmniejszyła się liczba dni ze średnią dobową temperaturą $\leq-10,0^{\circ} \mathrm{C}$, średnio o 3 dni w roku.

Przyczyn zaobserwowanych zmian klimatu Lublina w latach 1951-2010, przejawiających się w zmianie częstości średniej dobowej temperatury powietrza, nie można jednoznacznie określić. Jest to związane z faktem, że na zmiany klimatu w skali globalnej (IPCC 2013) nakładają się zmiany klimatu w skalach mniejszych, przede wszystkim w skali lokalnej. W analizowanym okresie powierzchnia Lublina wzrosła od ok. $30 \mathrm{~km}^{2}$ w roku 1951 do ponad $147 \mathrm{~km}^{2}$ W roku 2010, a liczba ludności ze 128 tys. do prawie 350 tys. (Potencjał... 2011, 
Rocznik... 1971). Wpłynęło to niewątpliwie na: zmiany w bilansie radiacyjnym miasta (związane m.in. ze wzrostem akumulacji energii słonecznej, zanieczyszczeniem powietrza i geometrią struktur urbanistycznych), zmniejszenie strat ciepła na parowanie oraz dodatkowe źródła ciepła antropogenicznego (szczególnie w okresie chłodnym). Dokładniejsze określenie wpływu rozwoju miasta na zmiany klimatu wymaga przeprowadzenia badań porównawczych warunków klimatycznych Lublina z obszarem pozamiejskim.

\section{LITERATURA}

Badach A., Gluza A.F., Kaszewski B.M., Niedziałek H., 1985. Temperatura powietrza w Lublinie w latach 1951-1980. Annales UMCS, sec. B, 60, 9, 169-193.

Czernecki B., Miętus M., 2010. Wstępna analiza występowania i zmienności termicznych pór roku $w$ wybranych regionach Polski na przykładzie Pasa Pobrzeży Poludniowobaltyckich $i$ Wyżyn Polskich, [w:] E. Bednorz (red.) Klimat Polski na tle klimatu Europy. Warunki termiczne i opadowe. Bogucki Wydawnictwo Naukowe, Poznań, 9-25.

Fiedorow E.E., 1925. Opytizuczenia pogody miesaca po pogodamotdielnychdniej, Żurnał Gieofiziki i Meteorologii, 2,3-4,5-16.

Fortuniak, K., Kłysik, K., Wibig, J., 2004. Międzydobowa zmienność temperatury powietrza w Łodzi, Acta Geographica Lodziensia, 89, 35-46.

IPCC,2013, Summary for Policy makers, [w:] Climate change 2013. The Physical Science Basis. Contribution of Working Group I to the Fifth Assessment Report of the Intergovernmental Panel on Climate Change. Cambridge University Press, Cambridge-New York.

Kaszewski B.M.,Gluza A.F., Siwek K., 2011. Występowanie niesprzyjających warunków termicznych dla uprawiania turystyki aktywnej na Lubelszczyźnie. Annales UMCS, LXVI,2, 91-101.

Kosowska-Cezak U., 2005. Warunki odczucia cieplnego określone na podstawie temperatury średniej dobowej (na przyktadzie Warszawy. Balneologia Polska 1-2/2005, 49-55

Kossowska-Cezak U., 2014. Zmiany wieloletnie średniej dobowej temperatury powietrza w Warszawie (1947-2013). Prz. Geof. 59, 127-139.

Kożuchowski K., 2004. Skala i tendencje wspótczesnych zmian temperatury powietrza w Polsce, [w:] K. Kożuchowski (red.) Skala uwarunkowania i perspektywy współczesnych zmian klimatycznych w Polsce, Łódź, 25-45.

Krępa E., Ciaranek D., 2014. Ekstremalne osobliwości w rocznym przebiegu temperatury powietrza w Krakowie. Prace Geograficzne, 139, Instytut Geografii i Gospodarki Przestrzennej UJ, Kraków, 57-67.

Mager P., Kopeć M., 2010. Okres wegetacyjny w Polsce i w Europie w dobie obserwowanego ocieplenia, [w:] E. Bednorz, L. Kolendowicz (red.), Klimat Polski na tle klimatu Europy - zmiany i ich konsekwencje, Bogucki Wyd. Nauk., Seria: Studia z Geografii i Geologii, 16, 49-63.

Michalska B., 2011. Tendencje zmian temperatury powietrza w Polsce. Prace i Studia Geograficzne, $47,67-75$.

Piotrowicz K., 2010. Sezonowa i wieloletnia zmienność typów pogody w Krakowie. Instytut Geografii i Gospodarki Przestrzennej Uniwersytetu Jagiellońskiego, Kraków. 
Potencjal ekonomiczny miast $w$ województwie lubelskim w latach 2000-2010. Analizy statystyczne. Urząd Statystyczny w Lublinie. Lublin, 2011.

Řezníčková L., Brázdil R., Tolarz R., 2007. Meteorological singularities in the Czech Republic in the period 1961-2002, Theoretical and Applied Climatology, 88, 179-192.

Rocznik Statystyczny Miasta Lublina 1971. Miejski Urząd Statystyczny w Lublinie. Rok I. Lublin 1971.

Wibig J., 2004. Bieg roczny i zmienność wieloletnia stopniodni chtodu i ciepła na obszarze Polski, [w:] K. Kożuchowski (red.) Skala uwarunkowania i perspektywy współczesnych zmian klimatycznych w Polsce, Łódź, 129-137.

Zinkiewicz W., Warakomski W., 1959. Zarys klimatu Lublina. Annales UMCS, vol. XIV, 2, Sectio B, 47-124.

\section{SUMMARY}

The paper summarizes the mean daily air temperature in Lublin (data from the Meteorological Station UMCS) in two 30-year periods: 1951-1980 and 1981-2010. The range of variability and frequency of air temperature values was analyzed in 2- and 5-degree intervals. The mean air temperature in the years $1981-2010$ was $8.7^{\circ} \mathrm{C}$ and it was higher than the mean air temperature for years $1951-1980$ for $0.8^{\circ} \mathrm{C}$. In the annual course during 10 months mean average monthly values were higher in the second period. The biggest differences concerned the months from January to March. The comparison of results obtained from two 30-year periods showed that the variability range of the mean daily air temperature has not changed (from $-25.9--24.0^{\circ} \mathrm{C}$ to $28.1-30.0^{\circ} \mathrm{C}$ ). However, the number of days with temperature $>20^{\circ} \mathrm{C}$ has significantly increased, on average by 6 days during the year, while the number of days with daily average temperature $\leq-10.0^{\circ} \mathrm{C}$ has decreased on average by 3 days in a year. In the annual course the highest changes in two analyzed periods are observed in January. In this month in the years 1981-2010 there was increase in the number of days with daily air temperature above $0.0^{\circ} \mathrm{C}$ by 4 days. 